\title{
Food Science and Technology International
}

http://fst.sagepub.com
Review: Loss of Quality during the Manufacture of Canned Fish Products
Food Science and Technology International 2001; 7; 199
DOI: 10.1106/4H8U-9GAD-VMG0-3GLR

The online version of this article can be found at: http://fst.sagepub.com/cgi/content/abstract/7/3/199

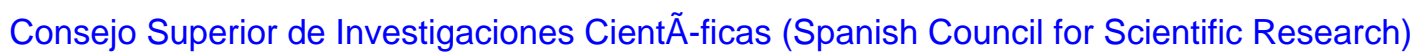

Additional services and information for Food Science and Technology International can be found at:

Email Alerts: http://fst.sagepub.com/cgi/alerts

Subscriptions: http://fst.sagepub.com/subscriptions

Reprints: http://www.sagepub.com/journalsReprints.nav

Permissions: http://www.sagepub.co.uk/journalsPermissions.nav

Citations http://fst.sagepub.com/cgi/content/refs/7/3/199 


\title{
Review: Loss of Quality during the Manufacture of Canned Fish Products
}

\author{
S.P. Aubourg* \\ Instituto de Investigaciones Marinas (CSIC), Eduardo Cabello 6, 36208 Vigo, Spain
}

\begin{abstract}
From the moment the fish is caught till it arrives at the consumer as a canned product, raw matter is submitted to a variety of industrial steps. Thus, a storage process (namely, chilling or freezing) is needed for holding the raw material to be canned; a cooking step is normally employed for reducing moisture and inactivating endogenous enzyme activity; a rigorous thermal treatment (sterilization) is undertaken to inactivate micro-organisms; and a proper canned storage is necessary to guarantee good palatability of the product. As a result, labile and essential nutrients (proteins, vitamins, lipids, minerals) present in the raw fish are exposed to different processing conditions that can reduce the nutritional and sensory values of the final product. In the present work, detrimental changes produced in each of the steps involved in the manufacture of canned products are mentioned. This review is focused on nutritional and sensory losses in species commonly employed for canning preparation, and special attention is given to research concerning the effect of varying conditions of previous processing (chilling, freezing and frozen storage and cooking) on the quality of the final canned product. New and current technological strategies are recommended to increase the shelf life of previously stored material and to retain sensory and nutritional quality in the final canned product.
\end{abstract}

Key Words: fish, chilling, freezing, cooking, sterilization, canning, quality

Desde la captura del pescado hasta que el producto enlatado llega al consumidor, la materia prima se somete a diversos tratamientos industriales. Se precisa de un proceso de conservación (fundamentalmente refrigeración o congelación) generalmente también se precisa de la cocción con el fin de reducir el exceso de humedad e inactivar las enzimas endógenas. Se emplea un tratamiento térmico enérgico (esterilización) para inactivar los microorganismos, y se precisa de un almacenamiento posterior adecuado para garantizar una buena palatabilidad del producto. Como resultado, los nutrientes lábiles y esenciales (proteínas, vitaminas, lípidos, minerales) presentes en la materia prima se ven expuestos a una variedad de condiciones de procesamiento que pueden reducir los valores nutricionales y sensoriales del producto final. En el este trabajo se describen los cambios negativos producidos en cada uno de los eslabones incluidos en la preparación de productos de pescado enlatados. La revisión se centra en las pérdidas nutritivas y sensoriales experimentadas por las especies normalmente empleadas en la elaboración de conservas. Se dedica una atención especial a la información referente al efecto de distintas condiciones de procesamiento previo (refrigeración, congelación y conservación en estado congelado, cocción) sobre la calidad del producto final enlatado. Finalmente, se recomienda el uso de tecnologías nuevas y tradicionales mejoradas con el fin de aumentar el tiempo de vida útil del material almacenado previamente y para retener las calidades sensoriales y nutricionales en el producto enlatado final.

Palabras Clave: pescado, refrigeración, congelación, cocción, esterilización, enlatado calidad

\section{INTRODUCTION}

Marine foods are known to provide high contents of important constituents for the human diet, such as nutritional and digestive proteins, lipid-soluble vitamins (A and $\mathrm{D}$, namely), microelements (I, F, Ca, Cu, Zn, Fe and others) and

*To whom correspondence should be sent

(e-mail: sauborg@nautilus.iim.csic.es).

Received 14 February 2000; revised 28 December 2000.

Food Sci Tech Int 2001;7(3):199-215

(C) 2001 Technomic Publishing Co., Inc.

ISSN: $1532-1738$

DOI: 10.1106/4H8U-9GAD-VMG0-3GLR highly unsaturated fatty acids (Piclet, 1987; Simopoulos, 1997). The lipid fraction is now the subject of a great deal of attention due to its high content on $\omega-3$ polyunsaturated fatty acids (PUFA), which have shown a positive role in preventing certain human diseases (Illingworth and Ullmann, 1990; Ackman and Ratnayake, 1990).

Marine products are obtained through a wide range of technological processes and have shown a great economic importance in many countries leading to annual export values higher than 50,000 US\$ millions in the latest years (FAO, 2000), however, they constitute a highly perishable food group (Cheftel and Cheftel, 1976; Pigott and Tucker, 1987). Fish deteriorates after death due to the action of different factors that can be summarized as microbiological de- 
velopment, endogenous enzyme activity, nonenzymatic lipid oxidation and browning. The relative incidence of each damage mechanism will depend on the kind of technological process applied.

Canning belongs to the most important means of fish preservation (Aitken and Connell, 1979; Horner, 1997). Many marine fish species produce excellent canned products, supporting an important role in the field of human nutrition and an annual export value around 2 millions tons in the latest years (FAO, 2000). Some marine species do not adapt to canning because the flesh disintegrates under the severe thermal processing conditions. This is the case with some lean fish, with their delicate flavor and structure, which are rendered virtually unmarketable by conventional canning processes. Thus, the consumer is accustomed to a limited variety of canned marine species. Among the most commonly canned species groups, the following can be mentioned from production in year 1998 (FAO, 2000): tunas and bonitos $(1,379,191 \mathrm{t})$, sardines $(557,272 \mathrm{t})$, molluscs $(402,530 \mathrm{t})$, herrings $(195,173 \mathrm{t})$, shrimps and prawns $(174,386 \mathrm{t})$ and salmons $(98,576 \mathrm{t})$.

As with any other treatment, canning should be designed to retain as much as possible of all the nutritional constituents present in the initial matter to serve human nutrition. The extensive heat treatment involved in the cooking and sterilization steps substantially alters the nature of the raw material so that, in effect, a product with different character-

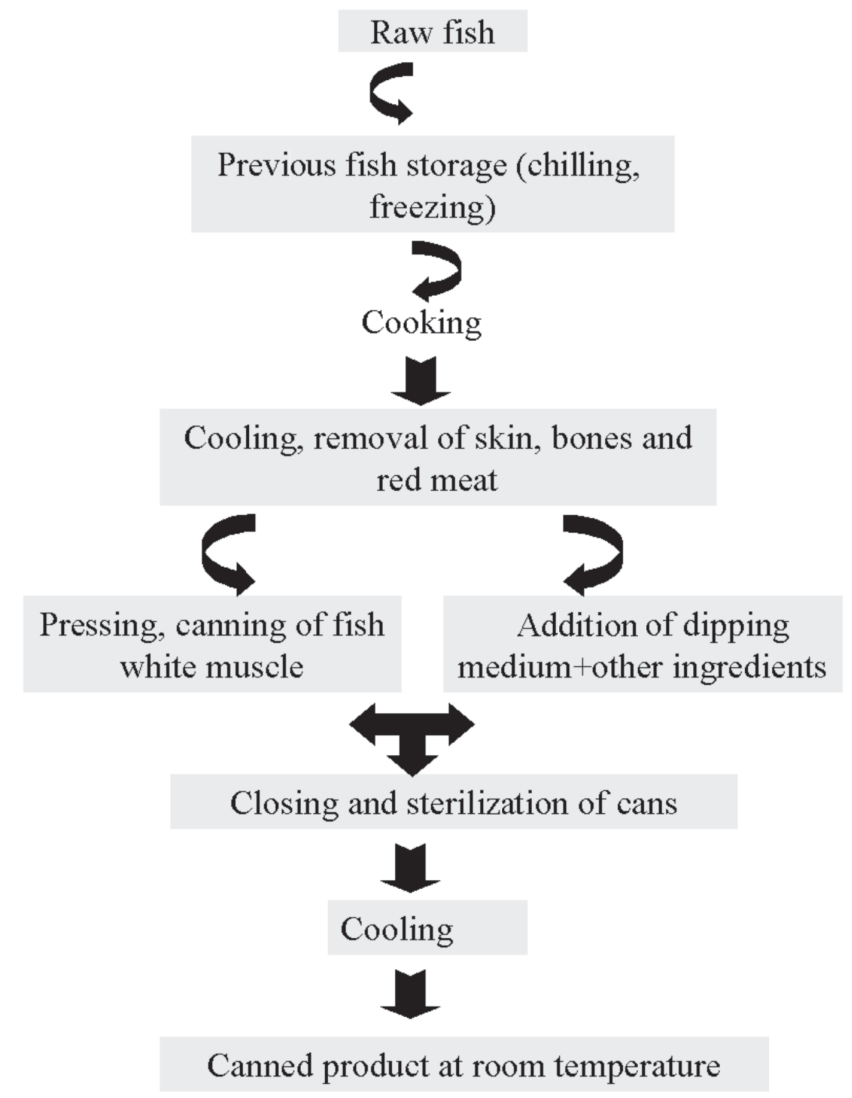

Figure 1. Steps included in the canned fish manufacture. istics is formed. Thus, both enzymes and bacteria should be permanently inactivated by heat and, provided reinfection does not occur and no negative interaction with the container is produced, heat processed fish keeps for a very long time.

Since most species used for canning occur in glut quantities, canneries often store the raw material before it is canned. Many of the problems with canned fish can be related to the quality of the raw material, which continuously changes during storage prior to processing. Two main strategies have been employed in countries where a developed technology is available, namely chilled and frozen storage. As a result, the quality of canned fish will also depend to a large extent on the adequacy of the methods used to hold the raw material.

The present work reviews information on fish quality deterioration from the moment it is captured till it is consumed as a canned product (Figure 1). Thus, quality changes produced during chilled storage, freezing and frozen storage, cooking, sterilization and canned storage are reviewed on marine species commonly employed in the elaboration of canned products. A special emphasis is given to studies concerning the effect of various conditions of previous processing (chilling, freezing, cooking) on the quality of the final canned product. Possible improvements to retain sensory and nutritional qualities in each step are then discussed.

\section{QUALITY CHANGES PRODUCED DURING THE CHILLED STORAGE}

Deterioration of marine species begins immediately upon capture, and the degree to which it continues depends directly on iced or refrigerated storage conditions. Much attention has been given to nutritional and sensory changes that marine species can undergo during the chilled storage; it has been proven that damage could be produced by the following factors (Whittle et al., 1990; Pigott and Tucker, 1990; Madrid et al., 1994; Ólafsdóttir et al., 1997):

(a) Microbial decomposition-Bacterial enzymes convert the trimethylamine oxide (TMAO) into trimethylamine (TMA) and decompose the amino acids and proteins forming ammonia, hydrogen sulfide and other undesirable compounds characteristic of microbial spoilage. Biogenic amines are also produced by the action of bacterial enzymes on free amino acids (histidine, tyrosine, tryptophan, lysine, ornithine and others); the greatest attention has been given to the histamine formation, which is reported to be responsible for the "scombrotoxic fish poisoning."

(b) Endogenous enzyme activity-Different pathways of autolysis in fish have been described. After the fish dies, lactic acid is produced by glycolysis. The drop in the $\mathrm{pH}$ value activates the protease activity, so that proteolysis is produced leading to free amino acid formation. At the 
same time nucleotides decompose; adenosine triphosphate (ATP) can lead through a several steps mechanism to inosine and hypoxanthine formation. Also lipases and phospholipases present in the fish muscle can produce lipid hydrolysis, so that free fatty acids, partially hydrolyzed lipids (diglycerides and monoglycerides), glycerine and nitrogenated bases can be produced. This wide variety of relatively small molecules can undergo further interactions with fish constituents leading to quality losses in the product.

(c) Lipid oxidation-Since marine lipids are highly unsaturated, contact with oxygen, especially in the presence of light or other catalysts, can lead to a wide range of lipid oxidation compounds (peroxides, carbonyls, interaction compounds) and loss of some essential and beneficial fatty acids for the human diet. Lipid oxidation compounds can interact with protein derivatives leading to nutritional losses in the product. This damage pathway can be more relevant as the fish fat content and storage temperature and time increase.

\section{Quality Changes during Chilled Storage of Marine Species Commonly Employed for Canning}

Important changes are known to take place during the chilled storage of species such as tuna, bonito, sardine, mackerel and herring. Freshness loss has been explained by some objective sensory, chemical and physical parameters. Detection of quality changes and the assessment of the shelflife time have been the main objectives.

\section{Sensory and Physical Analysis}

During chilled storage, sensory evaluation is currently the most important method for freshness evaluation. Characteristic sensory changes occur in appearance, odor, taste and texture of fish as long as the chill time increases (Ólafsdóttir et al., 1997); analysis is normally carried out by a sensory panel of trained professionals, so that fish is ranked into different categories (EC, 1989). A good correlation has been found between sensory scores and time in ice in albacore tuna (Pérez-Villarreal and Pozo, 1990) and sardine (Nunes et al., 1992; Ababouch et al., 1996). Small size species showed relatively low shelf-life times: 6 days for herring (Smith et al., 1980), 9 days for sardine (El Marrakchi et al., 1990) and 6-9 days for mackerel depending on the ice:fish ratio (Bennour et al., 1991). In contrast, bigger size fish species showed longer times; thus, whole albacore showed a shelf-life time of 20 days (Pérez-Villarreal and Pozo, 1990) and whole gutted salmon showed acceptable quality up to 20 days (Whittle et al., 1990).

Changes in physical properties such as texture, water holding capacity, electric properties or viscosity have been observed. Thus, Torrymeter readings (Nunes et al., 1992) and increases in $\mathrm{pH}$ values (Ababouch et al., 1996) in sardine have shown good correlation with sensory assessment. Torrymeter readings were shown to be an accurate method for assessing freshness in herring (Damoglou, 1980).

\section{Amine Formation and Nucleotide Degradation}

A sharp content increase of total volatile bases (TVB) and TMA has been observed to begin after 9-10 days of storage as a result of the end of the lag phase of microorganisms in sardine (El Marrakchi et al., 1990; Ababouch et al., 1996), mackerel (Bennour et al., 1991) and herring (whole and fillets) (Fernández-Salguero and Mackie, 1987). In the case of a higher size fish, TMA levels showed a sharp increase only after 20 days during albacore tuna storage (Pérez-Villarreal and Pozo, 1990), according to the sensory assessment mentioned.

Among biogenic amines, most efforts have been focused on histamine detection. Thus, content increase of such amine has been observed after 7-9 days of chilled storage in mackerel (Ababouch et al., 1996) and sardine (Table 1; Gallardo et al., 1997). Fernández-Salguero and Mackie (1987) showed an important increase in histamine and cadaverine contents during chilled storage of whole fish and fillets of herring.

Nucleotide degradation (ATP) has been observed to occur leading to a progressive formation of hypoxanthine with storage time in sardine (Nunes et al., 1992), horse mackerel (Smith et al., 1980) and salmon (Erikson et al., 1997); employment of the $k$-value showed a great correlation with sensory assessment and the storage time in albacore (Pérez-Villarreal and Pozo, 1990) and salmon (Erikson et al., 1997).

\section{Lipid Damage Analysis}

It was observed that shelf-life time in ice was longer for lean fish than for fatty fish; indeed, shelf life could vary within species with capture season according to the lipid content (Whittle et al., 1990; Nunes et al., 1992). Since fish species susceptible to canning are relatively fat, good correlation has been found between lipid damage and shelf life during chilled storage (Pigott and Tucker, 1987; Undeland et al., 1999).

During chilled storage of several fish species lipid hydro-

\section{Table 1. Histamine in various marine products, measured by capillary electrophoresis (adapted from Gallardo et al., 1997).}

\begin{tabular}{lc}
\hline Marine Product & Histamine (ppm) \\
\hline Fresh sardine & $<1(n=3)$ \\
Sardine (10 days in ice) & $40.76(n=3)$ \\
Sardine (13 days in ice) & $125.88(n=3)$ \\
Sardine $(15$ days in ice) & $211.52(n=3)$ \\
Fresh horse mackerel & $<1(n=3)$ \\
Horse mackerel $\left(24 \mathrm{~h}\right.$ at $\left.28^{\circ} \mathrm{C}\right)$ & $<1(n=3)$ \\
Fresh Atlantic mackerel & $378.47(n=3)$ \\
Atlantic mackerel $\left(48 \mathrm{~h}\right.$ at $\left.28^{\circ}\right)$ & $5169(n=2)$ \\
\hline
\end{tabular}


lysis has been detected in mackerel, herring and sardine (Smith et al., 1980; Hwang and Regenstein, 1993; Aubourg et al., 1997b), formation of peroxides (Smith et al., 1980; Undeland et al., 1999), thiobarbituric acid reactive substances (Nunes et al., 1992; Aubourg et al., 1997), interaction compounds (Aubourg et al., 1997; Undeland et al., 1999) and loss of endogenous antioxidants (Undeland et al., 1999).

Previous chill time was shown to exert a negative effect on the frozen shelf-life time of herring fillets (Undeland and Lingnert, 1999); it was observed that ice storage had a larger effect than the frozen storage on formation of peroxides and fluorescent compounds and disappearance of endogenous antioxidants ( $\alpha$-tocopherol and ascorbic acid).

\section{Effect of Previous Chilled Storage on Quality of Canned Products}

In spite of all these important changes that occur during the chilled storage, little research has been focused on studying the effect of different previous chilled conditions (time, temperature, ice/fish ratio) on the quality of the final canned products. Thus, Slabyj and True (1978) evaluated the effect of several chilled holding conditions ( 3 and $12 \%$ brine at $7.2^{\circ} \mathrm{C}$ and $0.6^{\circ} \mathrm{C}$ ) on the quality of the corresponding canned sardines. It was concluded that sardines have a relatively short shelf life, so that in order to obtain a final acceptable product, sardines should be canned within 36 hours, when lightly salted and held at $7.2^{\circ} \mathrm{C}$, and within 3 days when salted at higher salt concentration (12\% brine) and held at $0.6^{\circ} \mathrm{C}$. Lately (Aubourg and Medina, 1997), sardines were kept at $0{ }^{\circ} \mathrm{C}$ for up to 15 days; at different chill times $(0,2,6,10,13$ and 15 days), sardines were taken for cooking $\left(102-103^{\circ} \mathrm{C}\right)$ and sterilizing $\left(115^{\circ} \mathrm{C}, 45 \mathrm{~min} ; F_{\circ}=7\right.$

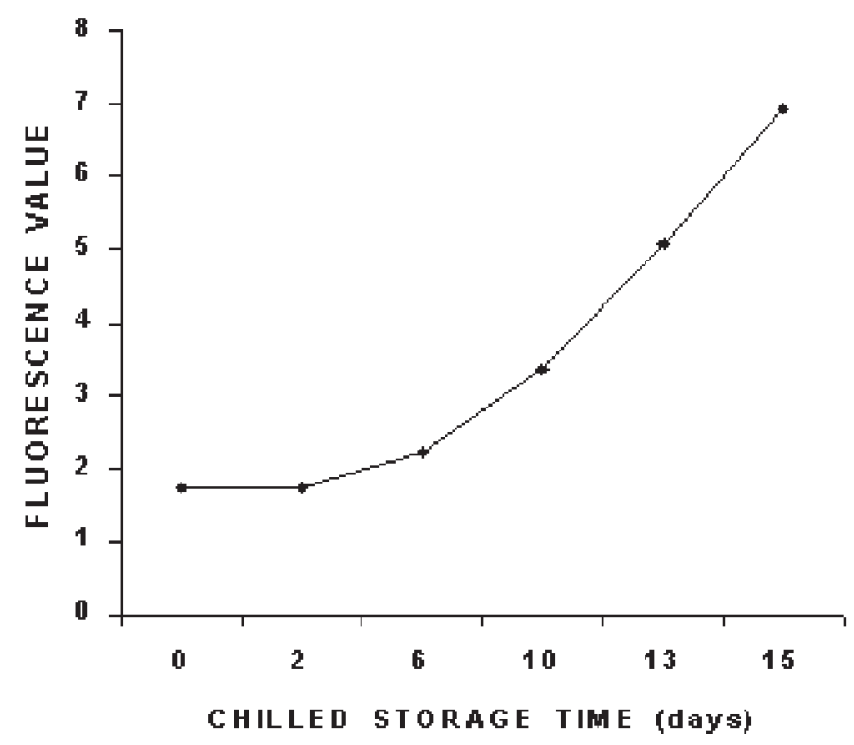

Figure 2. Fluorescent compound formation in canned sardine prepared from chilled starting material (adapted from Aubourg and Medina, 1997). $\min )$. After one year of canned storage, a negative effect was observed on previous chilled storage time in the canned product quality. Thus, a satisfactory nonlinear correlation value $(r=0.90)$ was obtained between the previous chilled storage time and the lipid damage in the canned sardine product (Figure 2). A great increase in lipid oxidation index (fluorescent compounds formation) was observed in canned samples that had been chilled longer than 6 days.

\section{QUALITY CHANGES PRODUCED DURING FREEZING AND FROZEN STORAGE}

As a result of the short shelf life of chilled fish, most excess material is kept frozen prior to canning. Freezing followed by frozen storage, is one of the best methods for fish preservation and has been employed increasingly both on shore and on board fishing vessels. Effects that make it possible to lengthen the storage life of fish muscle are the inhibition of microbial growth and the reduction of enzyme activity. However, measurement of sensory, chemical and physical changes have shown that deterioration of fish quality continues to some extent during frozen storage, since undesirable changes associated with lipids and proteins are produced. Studies on frozen fish have shown four different pathways of damage which lead to nutritional and sensory losses (Shenouda, 1980; Haard, 1992; Mackie, 1993; Xiong et al., 1997; Erickson, 1997):

(a) Protein denaturation and microstructural changes - The muscle becomes harder, more fibrous, less elastic and loses its water holding capacity. Toughening texture develops in edible muscle. As a result, proteins become more prone to damage and essential amino acids are more susceptible to loss.

(b) Lipid hydrolysis and oxidation-Endogenous enzymes (lipases, phospholipases; lipoxygenases, peroxidases) are still active during the frozen storage, especially if light or other catalysts (heme groups, transition metals) are present. As a result, loss of essential fatty acids are produced and a wide range of lipid oxidation and hydrolysis compounds are produced, most of them relatively small molecules, that are susceptible to interaction with fish constituents leading to a lowering in nutritional and sensory values of the product.

(c) Decomposition of TMAO into dimethylamine (DMA) and formaldehyde (FA)-This degradation is catalyzed by an endogenous enzyme (TMAO dimethylase). DMA produces detrimental odor and flavor and FA facilitates protein crosslinking, so that protein denaturation and toughening texture are produced. This damage pathway is especially important in the gadoid family, where a relatively high content of such endogenous enzymes is present. 
(d) Changes in myoglobin-Unaltered myoglobin is reported to be highly responsible for the bright of white muscle in good quality fish. During frozen storage this protein oxidizes to metmyoglobin, leading to important sensory quality losses of the fish product by means of a browning development in muscle.

\section{Freezing and Frozen Storage in Fish Species Commonly Employed for Canning}

Much research has been focused on how frozen storage impacts quality of marine species susceptible to canning. The loss of nutritional and sensory qualities and length of shelf life under several frozen temperatures have been the main objectives.

\section{Sensory and Physical Analyses}

Sensory evaluation indicated great differences in shelflife time in marine species, according to size, fat content and the presence of other constituents. In Table 2 are displayed for comparison the shelf-life time at $-22{ }^{\circ} \mathrm{C}$ for some marine species susceptible to canning (Madrid et al., 1994).

Albacore tuna oxidation began to develop after 6 months of storage at $-18{ }^{\circ} \mathrm{C}$, although most of the samples tested were of acceptable quality at month 12 (Ben-Gigirey et al., 1999). Refsgaard et al. (1998) followed the loss in sensory attributes in frozen $\left(-10,-20\right.$ and $\left.-30{ }^{\circ} \mathrm{C}\right)$ salmon fillets up to 34 weeks; at the end of this storage time, samples kept at the two lowest temperatures were still considered safe for eating.

Other experiments account for smaller size fish species. Anchovy showed a shorter shelf life but was still acceptable after 3 months at $-18{ }^{\circ} \mathrm{C}$ (Karaçam and Boran, 1996). Minced sardine was studied according to several sensory characteristics and was shown to be acceptable up to 90 days when kept at $-20^{\circ} \mathrm{C}$ (Table 3; Verma et al., 1995). Mackerel could be preserved safely under frozen storage $\left(-23{ }^{\circ} \mathrm{C}\right)$ for a period of 23-24 weeks (Nair et al., 1987). The sensory analysis of frozen $\left(-25{ }^{\circ} \mathrm{C}\right)$ squid (Illex patagonicus) showed that both tubes and arms maintained a good quality for 360 days, while the consumable quality was maintained for up to 420 days (Bykowski et al., 1990). No significant difference was obtained in the sensory attribute scores when
Table 2. Shelf-life time during frozen $\left(-22^{\circ} \mathrm{C}\right)$ storage of different marine species groups (adapted from Madrid et al., 1994).

\begin{tabular}{lc}
\hline Marine Species & Shelf Life (months) \\
\hline Lean fish & 24 \\
Flat fish & 24 \\
Tuna fish & 18 \\
Other fatty fish & 12 \\
Cephalopods & 24 \\
Non-cephalopod molluscs & 15 \\
Shrimp, prawn, lobster & 24 \\
Other crustaceans & 12 \\
\hline
\end{tabular}

comparing whole fish and fillets from frozen $\left(-18^{\circ} \mathrm{C}\right)$ horse mackerel (Simeonidou et al., 1997).

A wide variety of physical methods have been proposed to assess quality changes during frozen storage (Mallikarjunan and Hung, 1997; Barroso et al., 1998). Frozen storage resulted in a decrease in several physical properties (protein solubility, emulsifying capacity, relative viscosity, water holding capacity) in sardine at $-20{ }^{\circ} \mathrm{C}$ (Verma et al., 1995) and in $\mathrm{pH}$ and water holding capacity in horse mackerel (Simeonidou et al., 1997). Frozen $\left(-25^{\circ} \mathrm{C}\right)$ stored mackerel also showed a decrease in gel-forming capacity and jelly strength (Nishimoto and Koreeda, 1979).

\section{Amine Formation}

Increase in TMA, DMA, TVB and FA contents was observed during the frozen $\left(-18^{\circ} \mathrm{C}\right)$ storage of horse mackerel whole fish and fillets (Simeonidou et al., 1997); higher values in all cases were obtained for the fillet samples than for the whole fish. Ben-Gigirey et al. (1999) showed a progressive increase of DMA albacore during frozen storage at $-18^{\circ} \mathrm{C}$

Histamine formation was studied during frozen $\left(-20^{\circ} \mathrm{C}\right)$ storage of mackerel up to 33 weeks (Zotos et al., 1995). A great increase in its formation was observed after 11 weeks storage (Figure 3). In the same experiment, after being thawed, the frozen material was employed for further heatsmoking; thus, frozen storage time was shown to exert a favorable effect on the histamine formation in the final smoked product.

Table 3. Changes in sensory scores of frozen $\left(-20^{\circ} \mathrm{C}\right)$ sardine (adapted from Verma et al., 1995).

\begin{tabular}{|c|c|c|c|c|c|c|}
\hline \multirow[b]{2}{*}{ Sensory Evaluation* } & \multicolumn{6}{|c|}{ Frozen Storage Time (days) } \\
\hline & 0 & 30 & 60 & 90 & 120 & 150 \\
\hline Appearance & $4.0 \mathrm{a}$ & $3.6 \mathrm{a}$ & $3.0 \mathrm{~b}$ & $2.7 \mathrm{~b}$ & $1.9 \mathrm{c}$ & $1.5 \mathrm{c}$ \\
\hline Color & $4.0 \mathrm{a}$ & $3.1 \mathrm{~b}$ & $3.0 \mathrm{~b}$ & $2.7 \mathrm{~b}$ & $1.9 \mathrm{c}$ & $1.1 \mathrm{~d}$ \\
\hline Texture & $3.7 \mathrm{a}$ & $2.8 \mathrm{~b}$ & $2.8 \mathrm{~b}$ & $2.7 \mathrm{~b}$ & $1.7 \mathrm{c}$ & $1.3 \mathrm{c}$ \\
\hline Taste & $3.6 \mathrm{a}$ & $2.8 \mathrm{~b}$ & $2.7 \mathrm{~b}$ & $2.2 \mathrm{bc}$ & $1.6 \mathrm{~cd}$ & $1.3 \mathrm{~d}$ \\
\hline Overall acceptability & $3.9 a$ & $3.3 a b$ & $2.8 \mathrm{~b}$ & $2.7 \mathrm{~b}$ & $1.5 \mathrm{c}$ & $1.3 \mathrm{c}$ \\
\hline
\end{tabular}

*Scores obtained from 10 panelists; mean values within a row followed by different letters are significantly different $(p<0.05)$. 


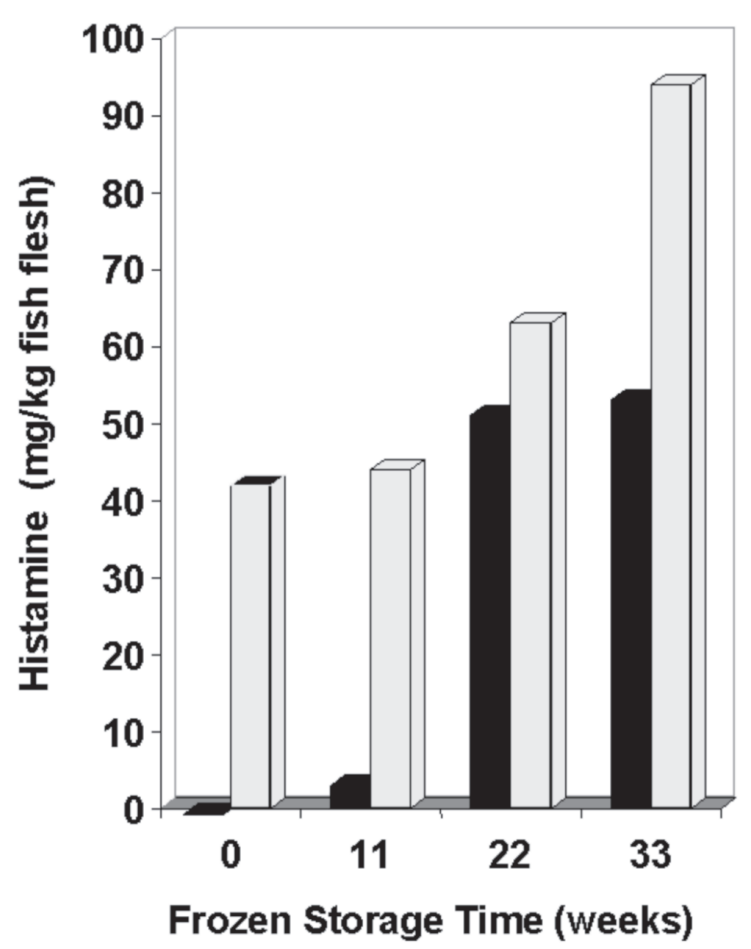

Figure 3. Histamine formation in frozen mackerel when thawed and then smoked (adapted from Zotos et al., 1995). Symbols: (口) thawed and ( $\square$ ) smoked.

\section{Lipid Damage Analysis}

A progressive development of hydrolysis (free fatty acids formation) with storage time was observed for a wide variety of species. Examples account for small size fish such as anchovy at $-18{ }^{\circ} \mathrm{C}$ (Karaçam and Boran, 1996), different muscle zones of mackerel at $-15,-30$ and $-40{ }^{\circ} \mathrm{C}$ (Ke et al., 1977), white and dark muscles of Baltic herring at $-15^{\circ} \mathrm{C}$ (Clupea harengus) (Bosund and Ganrot, 1969a) and mackerel $\left(-23^{\circ} \mathrm{C}\right)$ (Nair et al., 1987). Also in bigger size fish species such as Atlantic salmon (Refsgaard et al., 1998) and albacore tuna (Aubourg et al., 1989), it was observed that lipid hydrolysis was interrelated with lipid oxidation development (Han and Liston, 1987) and was retarded by lowering the temperature (Ke et al., 1977; Refsgaard et al., 1998).

Lipid oxidation was assessed by several methods. Peroxide formation was observed in anchovy $\left(-18{ }^{\circ} \mathrm{C}\right)$ (Karaçam and Boran, 1996), herring fillets at $-18^{\circ} \mathrm{C}$ (Undeland et al., 1998b), different parts of mackerel stored at $-15,-30$ and $-40{ }^{\circ} \mathrm{C}$ (Ke et al., 1977) and in Atlantic salmon at $-10,-20$ and $-30^{\circ} \mathrm{C}$ (Refsgaard et al., 1998).

Gas-liquid chromatography was also employed for assessing the volatile aldehydes and ketones during the frozen storage of Atlantic salmon (Refsgaard et al., 1998) and by studying changes in the 22:6/16:0 fatty acids ratio (Beltrán and Moral, 1989; Castrillón et al., 1996). HPLC was employed for assessing the loss of endogenous (tocopherol isomers) antioxidants (Undeland et al., 1998b; Refsgaard et al., 1998).
Development of secondary lipid oxidation compounds was detected by assessing the TBA reactive substances. Research accounts for frozen $\left(-18{ }^{\circ} \mathrm{C}\right)$ anchovy (Karaçam and Boran, 1996), mackerel $\left(-23^{\circ} \mathrm{C}\right)$ (Nair et al., 1987), different zones of Atlantic mackerel (Ke et al., 1977) and Atlantic salmon (Refsgaard et al. 1998). TBA index was employed successfully during the frozen $\left(-20^{\circ} \mathrm{C}\right)$ storage of two tuna species (skipjack and yellowfin) for predicting the shelf-life time (Kurade and Baranowski, 1987).

Finally, interaction compound formation by means of fluorescence detection and browning were determined in herring fillets (Undeland et al., 1998) and sardine (Aubourg et al., 1998).

\section{Protein and Amino Acid Changes}

As a result of sardine frozen $\left(-20^{\circ} \mathrm{C}\right)$ storage a significant loss of -SH groups was observed and also a loss of protein solubility; the amino acids which dropped the greatest extent were the S-amino acids, followed by histidine, tyrosine, leucine, lysine and phenylalanine (Castrillón et al., 1996). In the same experiment, digestibility of protein, biological value and net protein denaturation also dropped as a result of the processes studied.

The effect of free amino acids on denaturation of mackerel proteins during frozen $\left(-20{ }^{\circ} \mathrm{C}\right)$ storage was studied (Jian et al., 1987); it was concluded that the $\mathrm{NH}_{3}$ group of free amino acids (histidine, lysine, taurine, glycine, proline and glutamic acid) interacted with carbonyl groups on protein, so that in the case of histidine, lysine and taurine protein denaturation was accelerated.

The effect on protein changes during the frozen $\left(-20{ }^{\circ} \mathrm{C}\right)$ storage of mackerel (Scomber scombrus) was studied (Zotos et al., 1995). Protein denaturation, as related to salt-soluble protein, was influenced by the frozen storage time and seemed to be affected by the free amino acids formed during the frozen storage.

Accumulation of free fatty acids during the frozen storage has also been related to the detrimental effect on protein solubility and relative viscosity (Careche and Tejada, 1994) and to texture deterioration by interaction with proteins (Shenouda, 1980; Mackie, 1993).

\section{Effect of Previous Freezing and Frozen Storage on Quality of Canned Products}

Little research has been directed toward assessing the effect that previous frozen storage conditions (time and temperature) may have on the final quality of canned fish. Thus, the effect of frozen storage $\left(-28^{\circ} \mathrm{C}\right)$ of squid prior to thermal treatment (steaming at $100{ }^{\circ} \mathrm{C}$ and autoclaving at $115^{\circ} \mathrm{C}$ ) (Seidler and Bronowski, 1987) was found to exert no significant influence on the available lysine and triptophan contents of the flesh stored for no longer than 9-10 months of frozen storage. However, if longer frozen periods were employed, losses in amino acid, $-\mathrm{SH}$ group contents and fish weight after thermal treatment were observed. 


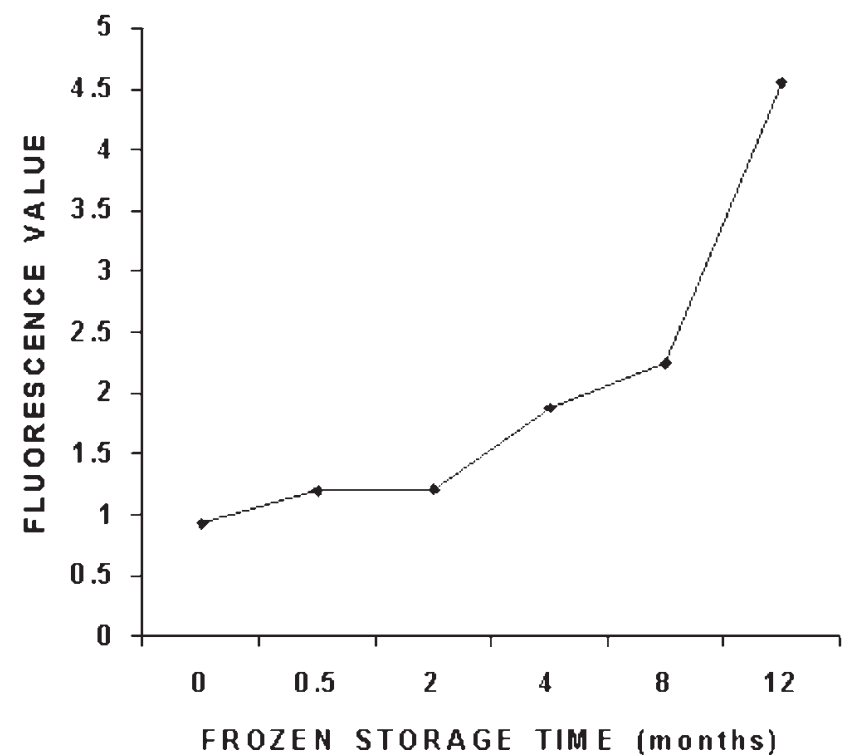

Figure 4. Fluorescent compound formation in canned sardine prepared from frozen $\left(-18^{\circ} \mathrm{C}\right)$ starting material (adapted from Aubourg and Medina, 1997).

In another experiment, sardine was kept frozen at $-18^{\circ} \mathrm{C}$ up to one year (Aubourg and Medina, 1997); at different times $(0,0.5,2,4,8$ and 12 months), sardines were taken for cooking $\left(102-103{ }^{\circ} \mathrm{C}\right)$, sterilizing $\left(115^{\circ} \mathrm{C}, 45 \mathrm{~min} ; F_{o}=7\right.$ min) and canned storage (12 months). A negative effect of previous frozen storage was observed for the final canned product quality. Thus, a satisfactory nonlinear correlation value ( $r=0.91$ ) was obtained between the previous frozen storage time and the lipid damage of the canned product if measured as the fluorescent compound development in the coating liquid medium (Figure 4). A significant increase in fluorescence produced was observed after 4 months of frozen storage; then, a sharp increase was obtained when considering 12 months storage. It was concluded that sardines should not be frozen longer than 4 months at $-18^{\circ} \mathrm{C}$ if acceptable nutritional and sensory properties were to be maintained in the final canned product.

ATPase activity decreased during frozen $\left(-25^{\circ} \mathrm{C}\right)$ storage of mackerel (Nishimoto and Koreeda, 1979), water-soluble fractions of fish muscle somewhat inhibited this decrease since rinsed samples showed a greater ATPase activity decrease.

Oxidation of bluefin tuna myoglobin was minimized by a quick freezing (very low temperature, ca. $-80{ }^{\circ} \mathrm{C}$ ) (Chow et al., 1987); these authors also observed that myoglobin autoxidation was $\mathrm{pH}$ dependent and was markedly accelerated by $\mathrm{NaCl}$ presence.

\section{COOKING}

During the canning process, cooking is employed to reduce excess moisture, so that the total exudate released in the canned product is minimum, the sensory, physical and chemical qualities of the product are improved and the shelf life is prolonged. After cooking and before being placed in cans, the fish is cooled in canneries by allowing it to stand at room temperature $\left(12-18^{\circ} \mathrm{C}\right)$, usually overnight.

The length of cooking is based on fish weight and initial temperature (Pérez-Martín et al., 1989). After processing, a relative increase in fat content is produced as a result of water loss (Gallardo et al., 1989; García Arias et al., 1994). Losses in moisture increase with the previous chill time, and fish having medium fat content lose more weight and moisture than those with higher fat content (Joshi and Saralaya, 1982).

The following damage pathways have been pointed out for the cooking treatment concerning the nutritional and sensory qualities, especially if over-processing is carried out (Cheftel et al., 1976; Pigott and Tucker, 1990): heat degradation of nutrients, oxidation of vitamins and lipids, leaching of water-soluble vitamins, minerals and proteins and toughening and drying of fragile protein fish.

\section{Quality Changes during Marine Species Cooking}

Since endogenous enzymes are inactivated and microbial development is stopped by heat, most attention during cooking has been given to lipid oxidation and further interaction of oxidized lipids with other constituents, proteins especially. At the same time, proteins are heat denatured as a result of the thermal treatment and turn into more reactive molecules.

\section{Lipid Damage}

Great attention is given to variations in the PUFA content. A wide range of experiments (Maeda et al., 1985; Hearn et al., 1987; Suzuki et al., 1988; Gallardo et al., 1989) showed no differences as a result of cooking in the content of PUFA (Table 4), even if different cooking conditions were checked (Gall et al., 1983); nor in other lipid oxidation indices such as the peroxide and iodine values, in spite of checking different albacore muscle zones with varying lipid content (Gallardo et al., 1989; Aubourg et al., 1989).

However, lipolysis (free fatty acids formation) and carbonyl compounds (TBA and carbonyl values) have been observed to develop by comparing the raw and cooked samples (Tichivangana and Morrisey, 1982; Yamamoto and Imose, 1989; Aubourg et al., 1995). Interaction compound formation between oxidized lipids and proteins have shown to be produced and were checked by browning and fluorescence detection (Aubourg et al., 1992, 1995). In fact, although neutral lipid classes were not affected by cooking, some phospholipid classes (phosphatidyl ethanolamine, namely) showed a significant decrease in content (Tichivangana and Morrisey, 1982; Yamamoto and Imose, 1989).

PUFA in sardines were stable to cooking, but unstable to oxidation during the subsequent refrigerated storage with a 
Table 4. Fatty acids content in white tuna muscle during different steps of canning process (adapted from García-Arias et al., 1994).

\begin{tabular}{|c|c|c|c|c|c|}
\hline \multirow{2}{*}{$\begin{array}{l}\text { Fatty Acids } \\
\text { (g/100 g fat) }\end{array}$} & \multicolumn{5}{|c|}{ Tuna Muscle* } \\
\hline & Raw & Cooked & Canned-0 & Canned-1 & Canned-3 \\
\hline $\mathrm{C} 14: 0$ & $3.1 \pm 0.35$ & $3.1 \pm 0.10$ & $1.6 \pm 0.14$ & $1.3 \pm 0.0$ & $1.4 \pm 0.04$ \\
\hline C15:0 & $1.2 \pm 0.05$ & $0.6 \pm 0.05$ & $0.3 \pm 0.00$ & $0.8 \pm 0.0$ & $0.2 \pm 0.02$ \\
\hline C16:0 & $21.4 \pm 1.00$ & $18.8 \pm 0.35$ & $15.2 \pm 0.10$ & $14.2 \pm 0.25$ & $15.4 \pm 0.31$ \\
\hline C:16, $n-7$ & $2.4 \pm 0.00$ & $2.7 \pm 0.30$ & $1.2 \pm 0.05$ & $0.8 \pm 0.10$ & $0.8 \pm 0.02$ \\
\hline C17:0 & $1.7 \pm 0.40$ & $0.8 \pm 0.05$ & $0.3 \pm 0.05$ & $0.2 \pm 0.00$ & $1.3 \pm 0.02$ \\
\hline C18:0 & $5.6 \pm 0.30$ & $5.4 \pm 0.30$ & $5.3 \pm 0.05$ & $4.3 \pm 0.35$ & $3.4 \pm 0.03$ \\
\hline C18:1, n-9 & $15.1 \pm 0.70$ & $18.5 \pm 0.20$ & $19.6 \pm 0.55$ & $21.3 \pm 0.10$ & $22.1 \pm 0.03$ \\
\hline C18:2, n-6 & $1.5 \pm 0.10$ & $1.3 \pm 0.35$ & $26.5 \pm 0.90$ & $35.3 \pm 0.55$ & $35.8 \pm 0.10$ \\
\hline C18:3, $n-3$ & $2.0 \pm 0.45$ & $2.4 \pm 0.65$ & $4.7 \pm 0.05$ & $6.1 \pm 0.60$ & $4.1 \pm 0.06$ \\
\hline C20:1, n-9 & $0.7 \pm 0.00$ & $1.7 \pm 0.15$ & $1.0 \pm 0.35$ & $0.8 \pm 0.00$ & 0.0 \\
\hline C18:4, n-3 & $0.1 \pm 0.05$ & $0.3 \pm 0.10$ & $0.1 \pm 0.05$ & $0.5 \pm 0.00$ & $0.4 \pm 0.06$ \\
\hline $\mathrm{C} 20: 4, n-6$ & $3.8 \pm 0.25$ & $3.6 \pm 0.05$ & $1.8 \pm 0.05$ & $1.1 \pm 0.20$ & $0.8 \pm 0.03$ \\
\hline $\mathrm{C} 22: 2, n-6$ & $0.5 \pm 0.00$ & $0.5 \pm 0.35$ & $0.1 \pm 0.05$ & $0.2 \pm 0.00$ & $0.1 \pm 0.03$ \\
\hline $\mathrm{C} 20: 5, n-3$ & $8.3 \pm 0.25$ & $8.2 \pm 0.45$ & $4.7 \pm 0.10$ & $2.8 \pm 0.20$ & $3.0 \pm 0.07$ \\
\hline $\mathrm{C} 22: 5, n-3$ & $1.9 \pm 0.10$ & $2.5 \pm 0.55$ & $1.1 \pm 0.25$ & $0.3 \pm 0.00$ & $0.1 \pm 0.01$ \\
\hline $\mathrm{C} 22: 6, n-3$ & $28.7 \pm 1.80$ & $27.6 \pm 0.35$ & $15.5 \pm 0.95$ & $9.5 \pm 0.60$ & $9.3 \pm 0.35$ \\
\hline
\end{tabular}

${ }^{*}$ Mean \pm SD, $n=4$. Canned-0, Canned-1 and Canned-3: Soya bean sterilized ( $\left.115^{\circ} \mathrm{C}\right)$ tuna for 55 min and then stored 0,1 and 3 years, respectively.

sharp increase in TBA value when increasing the storage time (Figure 5).

A positive role on quality has been observed for herring (Clupea harengus) cooking on lipid hydrolysis (Bosund and Ganrot, 1969) and oxidation (Bosund and Ganrot, 1970) during subsequent cold storage $\left(-15^{\circ} \mathrm{C}\right)$; it was suggested that the decrease in lipid damage during the frozen storage

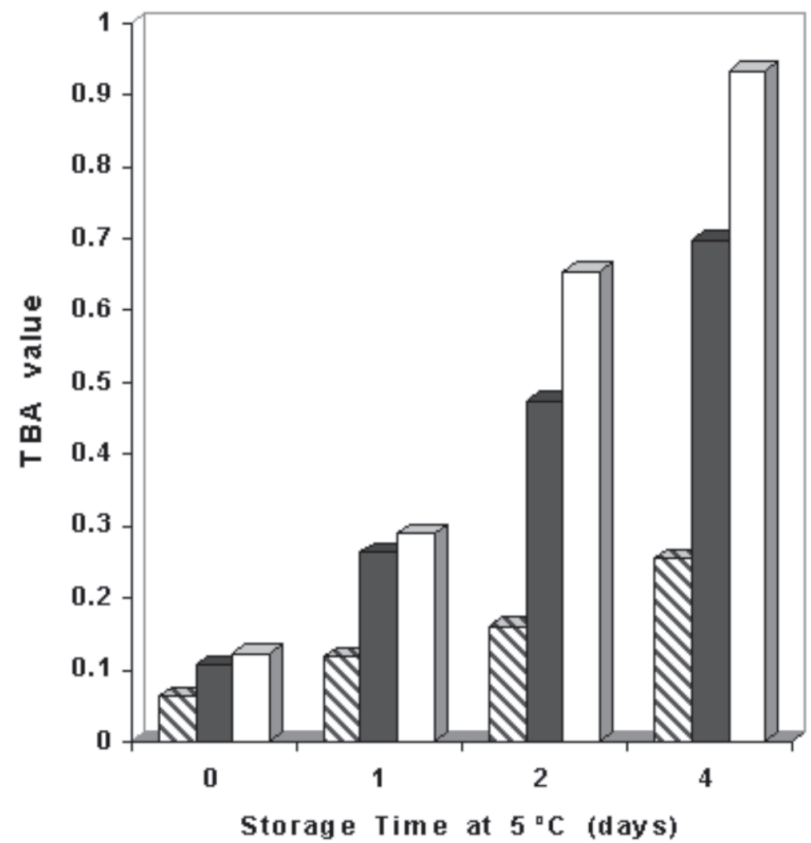

Figure 5. Development of tiobarbituric acid (TBA) reactive substances in sardine muscle by employing different heating conditions followed by a refrigerated storage (adapted from Yamamoto and Imose, 1989).

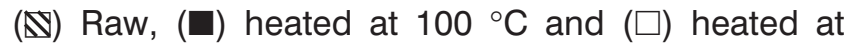
$170{ }^{\circ} \mathrm{C}$. could be due to either enzyme denaturation or to a decrease in the permeability of the muscle tissue to oxygen. Heat inactivation of lipoxygenase in lake herring (Coregonus artedii) was achieved with mild heating treatments ( $5 \mathrm{~min}$ at $80{ }^{\circ} \mathrm{C}$ ) (Wang et al., 1991).

Different cooking conditions (cooking time: 38 and 54 min; cooking temperature: $55^{\circ} \mathrm{C}$ and $100{ }^{\circ} \mathrm{C}$ ) were investigated in minced herring that was then kept frozen at $-18{ }^{\circ} \mathrm{C}$ (Undeland et al., 1998). Detection of peroxides, absorbance at 234 and $268 \mathrm{~nm}$ and lipid soluble fluorescent products showed that the best lipid stability in the frozen product was obtained at minimum cooking time and temperature. This finding was proposed to be due to heat inactivation of catalytic enzymes, without simultaneous activation of hemoproteins.

\section{Decomposition and Damage of Other Constituents}

The study of total free amino acid content during tuna cooking showed that no significant changes

Table 5. Changes in total free amino acid (TFAA) content of albacore (Thunnus alalunga) during thermal processing (adapted from Pérez-Martín et al., 1988).

\begin{tabular}{lc}
\hline Fish Sample & TFAA* $^{*}(\mathrm{mg} / 100 \mathrm{~g}, \mathrm{~d} . w)$. \\
\hline Raw & $3606.6 \mathrm{C}$ \\
Cooked & $3528.6 \mathrm{C}$ \\
Canned: $110^{\circ} \mathrm{C}, 90 \mathrm{~min}$ & $3070.5 \mathrm{~b}$ \\
Canned: $115^{\circ} \mathrm{C}, 60 \mathrm{~min}$ & $3188.6 \mathrm{~b}$ \\
Canned: $118^{\circ} \mathrm{C}, 45 \mathrm{~min}$ & $3301.7 \mathrm{bc}$ \\
Canned: $115^{\circ} \mathrm{C}, 100 \mathrm{~min}$ & $2416.4 \mathrm{a}$ \\
\hline
\end{tabular}

*Mean values of four independent determinations. Values followed by different letters are significantly different $(p<0.05)$. 
Table 6. Vitamin content changes during albacore (Thunnus alalunga) canning (adapted from Sett and Brown, 1983).

\begin{tabular}{lcccc}
\hline & \multicolumn{4}{c}{ Albacore* (Thunnus alalunga) } \\
\cline { 2 - 5 } Vitamins & Raw & Cooked & Canned: $115^{\circ} \mathrm{C}$, & $120 \mathrm{~min}$ \\
\hline Thiamine $(\mu \mathrm{g} / 100 \mathrm{~g})$ & $189 \pm 36 \mathrm{a}$ & $97 \pm 14 \mathrm{~b}$ & $9 \pm 0 \mathrm{c}$ & ${\mathrm{Canned:} 12{ }^{\circ} \mathrm{C},}_{95 \mathrm{~min}}$ \\
Riboflavin $(\mu \mathrm{g} / 100 \mathrm{~g})$ & $305 \pm 16 \mathrm{a}$ & $215 \pm 13 \mathrm{~b}$ & $150 \pm 28 \mathrm{c}$ & $11 \pm 3 \mathrm{c}$ \\
Niacin $(\mathrm{mg} / 100 \mathrm{~g})$ & $28 \pm 1 \mathrm{a}$ & $20 \pm 0 \mathrm{~b}$ & $20 \pm 1 \mathrm{~b}$ & $152 \pm 24 \mathrm{c}$ \\
\hline
\end{tabular}

*Mean values reported are on a dry weight basis. Within the same row, means followed by different letters are significantly different $(p<0.05)$.

were produced between raw and cooked samples (Table 5; Pérez-Martín et al., 1988; Castrillón et al., 1996b). However, some losses have been detected for total protein lysine (Seet and Brown, 1983; Castrillón et al., 1996) and great losses for some vitamins (thiamine and riboflavin) (Table 6) and minerals $(\mathrm{K}, \mathrm{Ca}$ and $\mathrm{Cu}$ ) content (Seet and Brown, 1983).

Assessment of TMAO decomposition and amine formation in albacore after cooking (Gallardo et al., 1990) produced a significant increase in TMA and TVB contents (Table 7).

Histamine values reached relatively high levels (above $100 \mathrm{ppm}$ ) as a result of histidine decomposition (Table 1) when mackerel and horse mackerel were over-processed by a thermal treatment (Gallardo et al., 1997).

\section{THE STERILIZATION STEP: GENERAL PROPERTIES}

Sterilization is the most drastic step carried out during the manufacture of canned fish and by definition guarantees the microbiological inactivity in the can. To keep the quality of the canned fish, the package has to satisfy the three following conditions (Stansby, 1979; Horner, 1997):

1. Hermetic seal of the can-The container seal integrity should be guaranteed, so that the content of the can is sterile all the time (López, 1987; Horner, 1997). Problems arise mainly from spore formers present in the unprocessed material in excessive number or, more commonly, gaining entry to the can after processing due to improper sealing or contaminated cooling water.

2. Adequate thermal process lethality-Times of exposure to given high temperatures should be employed so that an effective elimination of the most dangerous and heatresistant pathogens, particularly Clostridium botulinum, is undergone. Treatment required for sterilization of a product is dependent on the most inaccessible part of the food (cold spot) and is determined by heat penetration studies (Banga et al., 1991). Time and temperature employed depend on the geometry of the package, the characteristics of the product and container and the type of heating medium (steam, dry heat, oil, etc.) (Lund, 1975; Oliveira et al., 1986; Vieites et al., 1997).

3. Appropriate post-sterilization treatment and canned storage - A scrupulous and hygienic post-process should be carried out. After the sterilization process, the can while still hot and wet, is most vulnerable to leakage inward through the seal. Cooling water should be measurably chlorinated and wet cans should never be handled.

A 3-4 months canned storage is normally necessary to obtain advantageous textural changes and optimal palatability in most canned fish products (Kramer, 1982; RuizRoso et al., 1998). High storage temperatures (above $35^{\circ} \mathrm{C}$ ) must, at all costs, be avoided to prevent the outgrowth of thermophilic spores, which might survive the usual "botulinum process." The effect of the storage temperature is also very important if acid-marinated canned fish is stored over a relatively long (two years) period, because of the corrosive action of the constituents (López, 1987).

Table 7. Content changes in total volatile bases, individual bases and trimethylamine oxide during albacore (Thunnus alalunga) canning (adapted from Gallardo et al., 1990).

\begin{tabular}{|c|c|c|c|c|c|}
\hline \multirow[b]{2}{*}{ Volatile bases (mg N/kg) } & \multicolumn{5}{|c|}{ Albacore* (Thunnus alalunga) } \\
\hline & Raw & Cooked & $\mathrm{E}-1$ & $\mathrm{E}-2$ & E-3 \\
\hline TVB & $280(20)$ & $340(14)$ & $450(21)$ & $430(19)$ & $410(22)$ \\
\hline $\mathrm{NH}_{3}$ & $250(34)$ & $310(16)$ & $420(25)$ & $410(17)$ & $380(24)$ \\
\hline DMA & $2.4(0.6)$ & $5.2(1.9)$ & $7.0(1.9)$ & $7.4(1.7)$ & $7.7(1.5)$ \\
\hline TMA & $4.4(1.3)$ & $13(2.2)$ & $16(2.9)$ & 17 (3.3) & $19(4.1)$ \\
\hline TMAO & $19(6.3)$ & $8.4(4.9)$ & $4.2(2.5)$ & $3.3(1.9)$ & $1.9(2.1)$ \\
\hline
\end{tabular}

*Standard deviations are indicated in parentheses. E-1: caned at $110^{\circ} \mathrm{C}, 90 \mathrm{~min}, \mathrm{E}-2$ : canned at $115^{\circ} \mathrm{C}, 55 \mathrm{~min}$ and $\mathrm{E}-3$ : canned at $118^{\circ} \mathrm{C}, 40 \mathrm{~min}$. 


\section{QUALITY CHANGES PRODUCED AS A RESULT OF STERILIZATION AND CANNED STORAGE}

As a result of the sterilization step and further canned storage the following changes can be considered.

\section{The Filling Medium Effect}

Sterilization and subsequent canned storage can facilitate the drop of constituents to the coating medium. When an aqueous medium is employed, constituents such as amino acids, minerals and hydrophilic vitamins leach into the liquid medium of the can, leading to a significant loss of nutritional constituents if not consumed with the fish solids.

If canning is carried out in oil, fish muscle can also lose proteins, minerals and vitamins, since proteins are denatured by the heat process to the point of releasing a considerable amount of water to the headspace of the can. The water losses can vary in the range of 9-28\% depending on the severity of the sterilization and the previous cooking, species, $\mathrm{pH}$ and other physiological factors. It is necessary to limit such losses in the can, known as cook-out, otherwise it provides an unsightly, curdled appearance to the contents on opening the container. Oily-fleshed fish suffer less in this respect, due to the restrictive effect of the lipids on water migration.

When oil is employed as filling medium, interactions between fatty acids from the filling oil and the lipid fraction of the fish muscle occurs. There is in the flesh lipids a steep increase of the relative proportion of fatty acids abundant in the filling oil (Table 4). At the same time, the characteristic fatty acids of the flesh lipids have been shown to be present in the filling oil after canning and canned storage (Table 8) (Aubourg et al., 1990; García Arias et al., 1994; Aubourg et al., 1995b; Ruiz-Roso et al., 1998). This interaction between both kinds of lipid material increased with a long-term canned storage (Table 4) (García Arias et al., 1994; Aubourg, 1998). As a result, the use of filling media having high PUFA content has been recommended to retain the positive medical benefits of $\omega 3$-PUFA present in marine products (Hale and Brown, 1983).

\section{Minerals and Vitamins}

Some loss in minerals ( $\mathrm{Na}, \mathrm{K}, \mathrm{Mg}, \mathrm{P}, \mathrm{Cu}, \mathrm{Fe}, \mathrm{Ca}$ ) from the muscle into the dipping medium occurs in canned tuna (Seet and Brown, 1983). It was observed that higher fat content in the flesh produced lower losses of minerals, indicating a kind of interaction between both types of constituents (Gall et al., 1983). An advantage of fish canning is that bones become soft textured and thus edible, providing an important calcium source (March, 1982).

The heat-labile vitamins thiamine, riboflavin, niacin, pyridoxine and pantothenic acid are the nutrients most damaged by the sterilization process (Table 6). Varying results
Table 8. Fatty acid composition of raw and canned little tunny (Euthynnus alletteratus) lipids

(adapted from Aubourg et al., 1995).

\begin{tabular}{|c|c|c|c|}
\hline \multirow[b]{2}{*}{ Fatty Acid (\%) } & \multicolumn{3}{|c|}{ Little Tunny* (Euthynnus alletteratus) } \\
\hline & Raw & Brine Canned & Oil Canned \\
\hline C14:0 & $1.6 \pm 0.2$ & $1.7 \pm 0.4$ & $0.7 \pm 0.4$ \\
\hline C15:0 & $0.6 \pm 0.1$ & $0.5 \pm 0.1$ & $0.2 \pm 0.1$ \\
\hline C16:0 & $22.3 \pm 1.1$ & $21.5 \pm 0.7$ & $14.8 \pm 1.4$ \\
\hline 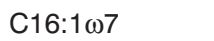 & $2.7 \pm 0.3$ & $2.2 \pm 0.2$ & $1.3 \pm 0.3$ \\
\hline C17:0 & $1.2 \pm 0.1$ & $1.1 \pm 0.1$ & $0.4 \pm 0.1$ \\
\hline C18:0 & $7.9 \pm 0.1$ & $9.1 \pm 0.7$ & $5.8 \pm 0.2$ \\
\hline $\mathrm{C} 18: 1(\omega 9+\omega 7)$ & $14.0 \pm 1.4$ & $14.1 \pm 0.7$ & $54.6 \pm 5.5$ \\
\hline $\mathrm{C} 18: 2 \omega 6$ & $0.9 \pm 0.1$ & $1.1 \pm 0.1$ & $4.7 \pm 0.5$ \\
\hline $\mathrm{C} 18: 3 \omega 3$ & $0.9 \pm 0.1$ & $0.5 \pm 0.0$ & $0.4 \pm 0.0$ \\
\hline $\mathrm{C} 20: 1 \omega 9$ & $0.7 \pm 0.1$ & $0.7 \pm 0.1$ & $0.4 \pm 0.1$ \\
\hline 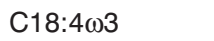 & $0.8 \pm 0.1$ & $0.2 \pm 0.0$ & $0.2 \pm 0.0$ \\
\hline $\mathrm{C} 20: 4 \omega 6$ & $2.9 \pm 0.5$ & $3.5 \pm 0.3$ & $1.2 \pm 0.2$ \\
\hline 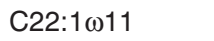 & $0.7 \pm 0.2$ & $0.6 \pm 0.2$ & $0.2 \pm 0.1$ \\
\hline $\mathrm{C} 20: 4 \omega 3$ & $0.6 \pm 0.1$ & $0.6 \pm 0.3$ & $0.2 \pm 0.0$ \\
\hline $\mathrm{C} 20: 5 \omega 3$ & $6.7 \pm 0.3$ & $6.6 \pm 0.4$ & $2.2 \pm 0.7$ \\
\hline $\mathrm{C} 24: 0$ & $0.4 \pm 0.1$ & $0.3 \pm 0.1$ & $0.1 \pm 0.0$ \\
\hline $\mathrm{C} 22: 4 \omega 6$ & $0.4 \pm 0.3$ & $0.7 \pm 0.1$ & $0.3 \pm 0.0$ \\
\hline $\mathrm{C} 24: 1 \omega 9$ & $2.1 \pm 0.4$ & $1.8 \pm 0.1$ & $0.6 \pm 0.1$ \\
\hline $\mathrm{C} 22: 5 \omega 3$ & $1.5 \pm 0.1$ & $1.4 \pm 0.1$ & $0.5 \pm 0.2$ \\
\hline $\mathrm{C} 22: 6 \omega 3$ & $30.3 \pm 1.4$ & $30.6 \pm 1.3$ & $10.5 \pm 2.2$ \\
\hline
\end{tabular}

* Mean \pm SD, $n=4$. Initial olive oil composition (\%): 10.1 (16:0), 2.9 (18:0), $75.7(18: 1)$ and $9.5(18: 2 \omega 6)$

have been described for vitamin losses (5-80\% for thiamine; 71-73\% for niacin; 49-50\% for riboflavin) (Bentereud, 1977; Seet and Brown, 1983; Banga et al., 1993b). However the most abundant vitamins (A and D) are acceptably retained (Bender, 1987).

\section{Volatile and Biogenic Amines}

TMAO can be degraded during the thermal processing to disagreeable molecules such as TMA and DMA (Yeannes et al., 1983; Gallardo et al., 1990). Thus, among different experiments a gradual increase in such volatile bases measured as TVB or as individual amines (DMA and TMA) has been observed by comparing the raw material and the final canned product (Tokunaga, 1975; Yeannes et al., 1983; Besteiro et al. 1993). Gallardo et al. (1990) proved an increasing tendency: raw < cooked < canned for TVB and the individual amines, while TMAO showed the inverse tendency (Table 7). It was observed that if good quality raw material was employed (25-30 mg TVB/100 g muscle) and an appropriate sterilization treatment was carried out $\left(F_{o}=7 \mathrm{~min}\right)$, canned samples would be within a satisfactory and acceptable range (40-45 mg TVB/100 g muscle).

No relevant formation of histamine and other biogenic amines has been detected when raw material in good condition is used; in those cases no significant differences were obtained between the fresh and canned samples (LópezSabater et al., 1994; Veciana-Nogués et al., 1997). Cadaverine and putrescine contents showed a good correla- 
Table 9. Contents variation of inosine monophosphate, inosine and hypoxanthine throughout tuna canning (adapted from Veciana-Nogués et al., 1997).

\begin{tabular}{lccc}
\hline Processing Step & Inosine Monophosphate & Inosine $(\mu$ moles $/ g$ fish muscle $)$ & Hypoxanthine \\
\hline Raw fish & 4.65 & 3.25 & 0.80 \\
Before cooking & 4.40 & 2.70 & 1.25 \\
After cooking & 4.35 & 2.10 & 1.05 \\
After packing & 4.45 & 2.95 & 1.3 \\
End product & 3.10 & 2.75 & 1.35 \\
\hline
\end{tabular}

tion with sensory quality in canned skipjack tuna (Sims et al., 1992).

\section{Nucleotide Degradation Products}

Inosine monophosphate, inosine and hypoxanthine were determined along different steps of the canning process ( $\mathrm{Ta}$ ble 9; Veciana-Nogués et al., 1997). Since none of these compounds were produced by heat treatments and also because their contents did not decrease with cooking or sterilization processes, such molecules were found to be appropriate as a quality index to assess the raw fish quality. However, Rodríguez et al. (1996) reported that when very vigorous treatments are involved, only hypoxanthine remained constant throughout the process of canning fish.

Gill et al. (1987) showed a good correlation between the hypoxanthine content in canned yellowfin tuna and the previous storage time of raw material at $10^{\circ} \mathrm{C}$ and $18^{\circ} \mathrm{C}$.

\section{Lipids}

The strong heat treatment and the presence of some catalysts in the fish muscle can favor nonenzymatic lipid oxidation and hydrolysis so that detrimental flavor and essential nutrient losses can be produced (Hsieh and Kinsella, 1989; Harris and Tall, 1994).

\section{Hydrolysis}

A significant formation of free fatty acids occurred during the sterilization of different muscle zones of albacore (Aubourg et al., 1990). An analysis by a ${ }^{13} \mathrm{C}-\mathrm{NMR}$ study proved that hydrolysis was produced preferentially in the sn2 position of triglycerides instead of in the sn- 1 and sn- 3 locations, as during the frozen storage (Medina et al., 1994). The mechanism and extension of hydrolysis were independent of the filling medium employed, oil or brine (Medina et al., 1995). A comparison of different time/temperature sterilizing conditions ( $F_{o}=7 \mathrm{~min}$ in all cases) showed that treatments with shorter times but higher temperatures lead to a higher hydrolysis development (Aubourg et al., 1997).

\section{Oxidation}

Studies concerning lipid oxidation have been focused on PUFA composition. No significant changes in PUFA con- centrations due to heat processing in sealed cans were detected in sardine, mackerel and herring (Hale and Brown, 1983), tuna (Aubourg et al., 1990) and crab (Giddings and Hill, 1975). However, plasmalogen-type molecules were shown to be very labile, so that a great decrease was observed as a result of a standard sterilization treatment $\left(F_{o}=7\right.$ min) in both brine and oil when employed as coating medium (Table 10) (Medina et al., 1993; Aubourg et al., 1995b).

Primary (peroxide value; conjugated dienes) and secondary (TBA and carbonyl values) lipid oxidation detections did not afford accurate methods for testing quality differences in canned products (Aubourg et al., 1995a; Aubourg and Medina, 1997). On the basis that oxidation compounds are reacting with other fish constituents, detection of such interaction compounds by their fluorescent properties provided an accurate tool for assessing the degree of damage of a canned product. This fluorescence detection showed an important relationship to raw material quality and the extent of the thermal treatment (Aubourg et al., 1992; Aubourg and Medina, 1997).

\section{Free Amino Acids and Proteins}

Heat denaturation of proteins does not necessarily cause nutritional loss. However, it is known that denatured proteins become more reactive and can be damaged easily by interacting with other constituents. The total free amino acids content decreased during tuna canning, especially if over-processing was employed (Table 5). It was postulated that free amino acids would have been lost as a result of being extracted by the dipping medium and/or interaction reactions with oxidized lipids. As a result, this detection was rec-

Table 10. Content of plasmalogen-type compounds during thermal processing of albacore (Thunnus alalunga) (adapted from Medina et al., 1993).

\begin{tabular}{lccc}
\hline & \multicolumn{3}{c}{ Alkenyl Ether Chains } \\
\cline { 2 - 4 } Fish Sample & C16:0 (\%) & C18:0 (\%) & C18:1 (\%) \\
\hline Raw & $7.27 \pm 0.47 \mathrm{a}$ & $2.01 \pm 0.21 \mathrm{~b}$ & $1.17 \pm 0.14 \mathrm{~b}$ \\
Cooked & $8.99 \pm 0.67 \mathrm{~b}$ & $2.45 \pm 0.13 \mathrm{~b}$ & $1.37 \pm 0.15 \mathrm{~b}$ \\
Brine canned & $3.86 \pm 0.29 \mathrm{a}$ & $1.09 \pm 0.08 \mathrm{a}$ & $0.61 \pm 0.05 \mathrm{a}$ \\
Oil canned & $4.07 \pm 0.37 \mathrm{a}$ & $1.01 \pm 0.16 \mathrm{a}$ & $0.63 \pm 0.09 \mathrm{a}$ \\
\hline
\end{tabular}

*Mean $\pm \mathrm{SD}, n=6$. Values in the same column followed by different letters are significantly different. 
ognized as a possible useful tool to assess the extent of thermal treatment during sterilization (Pérez-Martín et al., 1988).

Several studies have been published on changes in individual amino acids caused by heating. Some losses in essential amino acids have been reported, except for histidine and the sulfuric amino acids (Geiger and Borgstrom, 1962; Tanaka and Kimura, 1988). A retention of $80-85 \%$ in lysine for canned tuna (Seet and Brown, 1983) was detected; its thermal degradation in tuna white muscle was found to be a first-order kinetic process (Banga et al., 1992) and overprocessing was shown to reduce lysine content in canned tuna (Castrillón et al., 1996). As a result, it is accepted that if standard procedures are employed, quality of canned fish proteins remains after the process (Bender, 1987; Banga et al., 1992).

Other kinds of protein analysis widely employed include digestibility. Hurrel and Carpenter (1977) postulated that in fish, due to the small quantity of reducing sugars present, the losses of protein digestibility was small; however, Tanaka and Kimura (1988) found significant changes in protein digestibility after thermal processing of bigeye tuna. Banga et al. (1992) found for protein digestibility an empirical pseudo $n$-order kinetic model and no significant differences were obtained after standard thermal processing. In this sense, protein digestibility, biological value and net protein utilization remained unchanged if over-processing was not employed (Castrillón et al., 1996).

\section{FINAL REMARKS}

Canning is a multistep process. Actual research shows that previous processing (chilling, freezing, cooking) until sterilization and canned storage can lead to the formation of a wide number of metabolites, most of them relatively small molecules, that can interact with fish constituents (proteins, especially) to produce quality losses. Also, beneficial constituents (proteins, unsaturated fatty acids, vitamins) can break down during such pretreatments and be lost in the final product.

Most research has been carried out concerning changes produced in each of the individual steps included in the manufacture of canned products. However, very few studies have been achieved to check the effect that varying conditions of chilling, freezing and frozen storage and cooking can exert on the final canned product quality. In this sense, more complete experiments are necessary to assess the relative influence of each technological step on the nutritional and sensory quality.

Since fish chilling can lead to a great microbial and autolytic development, most actual efforts including appropriate traditional and new strategies focused on stopping such damage pathways, so that high quality raw material is then thermally treated. The shelf life in the case of the chilled storage is being prolonged by employing modified atmosphere, vacuum packaging and irradiation treatments (Whittle et al., 1990; Loaharanu, 1995; Davies, 1997).

As most species employed for canning are medium and high fat content, most efforts during the frozen storage have been focused on avoiding lipid damage and consequent nutritional loss and accordingly, enlarging the shelf life of fish species. In this sense, a great deal of attention is being given to the antioxidants (Erickson, 1997; Decker, 1998), cryoprotectants (MacDonald and Lanier, 1997) and edible coatings and films (Baker et al., 1994; Callegarin et al., 1997) employed. Recent research is now especially aimed at the replacement of synthetic antioxidants by natural ones (Frankel, 1995); naturally occurring antioxidants have successfully been employed with minced fish (Kelleher et al., 1992; Boyd et al., 1993) and whole or filleted fish (Vareltzis et al., 1997; Khalil and Mansour, 1998).

The thermal treatment (cooking and sterilization) can lead to breakdown and further interactions of a wide number of fish constituents. Actual research shows that when accurate time/temperature conditions are employed during both thermal treatments, the retention degree of most of the fish constituents remains at an acceptable level, provided high quality raw material is employed. In order to obtain maximum nutrient retention, some recent developments as sous-vide cooking (Schellekens, 1996), optimization strategies and process control by computer (Banga et al., 1993a) and employment of filling media including antioxidant components (Medina et al., 1998) have been investigated successfully and their practice is now encouraged.

\section{ACKNOWLEDGEMENTS}

The author acknowledges financial support for the Research Projects: ALI 88-0145-C02-02 (CICyT, Spain), ALI 90-0773 (CICyT, Spain) and XUGA 402 01B93 (Xunta de Galicia, Spain).

\section{REFERENCES}

Ababouch L., Souibri L., Rhaliby K., Ouahdi O., Battal M. and Busta F. (1996). Quality changes in sardines (Sardina pilchardus) stored in ice and at ambient temperature. Food Microbiology 13: 123-132.

Ackman R. and Ratnayake W. (1990). Chemical and analytical aspects of assuring an effective supply of omega-3 fatty acids to the consumer. In: Lees R. and Karel M. (eds), Omega3 Fatty Acids in Health and Disease. New York and Basel: Marcel Dekker, Inc. pp. 215-233.

Aitken A. and Connell J. (1979). Fish. In: Priestley R. (ed.), Effects of Heating on Food Stuffs. London: Applied Science Publishers Ltd. pp. 219-254.

Aubourg S. (1998). Lipid changes during long-term storage of canned tuna (Thunnus alalunga). Zeitschrift für Lebensmittel-Untersuchung und Forschung 206: 33-37. 
Aubourg S. and Medina I. (1997). Quality differences assessment in canned sardine (Sardina pilchardus) by detection of fluorescent compounds. Journal of Agricultural and Food Chemistry 45: 3617-3621.

Aubourg S., Gallardo J. and Medina I. (1997). Changes in lipids during different sterilising conditions of albacore tuna (Thunnus alalunga) canning. International Journal of Food Science and Technology 32: 427-432.

Aubourg S., Medina I. and Pérez-Martín R. (1995). A comparison between conventional and fluorescence detection methods of cooking-induced damage to tuna fish lipids. Zeitschrift für Lebensmittel-Untersuchung und Forschung 200: $252-255$.

Aubourg S., Medina I., Gallardo J. and Pérez-Martín R. (1995). Efecto del enlatado en aceite y salmuera y su posterior almacenamiento sobre los lípidos de la bacoreta (Euthynnus alletteratus). Grasas y Aceites 46: 77-84.

Aubourg S., Pérez-Martín R. and Gallardo J. (1989). Stability of frozen albacore (Thunnus alalunga) during steam cooking. International Journal of Food Science and Technology 24: $341-345$

Aubourg S., Pérez-Martín R., Medina I. and Gallardo J. (1992). Fluorescence formation during albacore (Thunnus alalunga) thermal processing. Zeitschrift für LebensmittelUntersuchung und Forschung 195: 332-335.

Aubourg S., Sotelo C. and Gallardo J. (1990). Changes in flesh lipids and fill oils of albacore (Thunnus alalunga) during canning and storage. Journal of Agricultural and Food Chemistry 38: 809-812.

Aubourg S., Sotelo C. and Gallardo J. (1997). Quality assessment of sardines during storage by measurement of fluorescent compounds. Journal of Food Science 62: 295-299.

Aubourg S., Sotelo C. and Pérez-Martín R. (1998). Assessment of quality changes in frozen sardine (Sardina pilchardus) by fluorescence detection. Journal of the American Oil Chemists' Society 75: 575-580.

Baker R., Baldwin E. and Nísperos-Carriedo M. (1994). Edible coatings and films for processed foods. In: Krochta, J., Baldwin, E. and Nísperos-Carriedo, M. (eds), Edible Coatings and Films to Improve Food Quality. Lancaster-Basel: Technomic Publishing Co., Inc. pp. 89-104.

Banga J., Alonso A., Gallardo J. and Pérez-Martín R. (1992). Degradation kinetics of protein digestibility and available lysine during thermal processing of tuna. Journal of Food Science 57: 913-915.

Banga J., Alonso A., Gallardo J. and Pérez-Martín R. (1993a). Mathematical modelling and simulation of the thermal processing of anisotropic and non-homogeneous conductionheated canned foods: Application to canned tuna. Journal of Food Engineering 18: 369-387.

Banga J., Alonso A., Gallardo J. and Pérez-Martín R. (1993b). Kinetics of thermal degradation of thiamine and surface colour in canned tuna. Zeitschrift für LebensmittelUntersuchung und Forschung 197: 127-131.

Banga J., Pérez-Martín R., Gallardo J. and Casares J. (1991). Optimization of the thermal processing of conductionheated canned foods: Study of several objective functions. Journal of Food Engineering 14: 25-51.
Barroso M., Careche M. and Borderías J. (1998). Quality control of frozen fish using rheological techniques. Trends in Food Science and Technology 9: 223-229.

Beltrán A. and Moral A. (1989). Effect of smoking on lipid stability in sardine (Sardina pilchardus W.). Zeitschrift für Lebensmittel- Untersuchung und Forschung 189: 317-321.

Bender A. (1987). Food Processing and Nutrition. London: Academic Press. pp. 27-80.

Ben-Gigirey B., Vieites J., Villa T. and Barros-Velázquez J. (1999). Biochemical changes and visual appearance of albacore tuna as related to frozen storage. Journal of Food Science 64: 20-24.

Bennour M., El Marrakchi A., Bouchriti N., Hamama A. and El Ouadaa M. (1991). Chemical and microbiological assessments of mackerel (Scomber scombrus) stored in ice. Journal of Food Protection 54: 784, 789-792.

Bentereud A. (1977). Vitamin losses during thermal processing. In: Høyem T. and Kvale O. (eds.), Physical, Chemical and Biological Changes in Food Caused by Thermal Processing. London: Applied Science Publishers. pp. 185-201.

Besteiro I., Rodríguez C., Tilves F. and Pascual C. (1993). Análisis sensorial, variaciones en la composición y evolución de compuestos nitrogenados durante la elaboración de conservas de atún. Alimentaria Diciembre: 49-54.

Bosund I. and Ganrot B. (1969a). Lipid hydrolysis in frozen Baltic herring. Journal of Food Science 34: 13-18.

Bosund I. and Ganrot B. (1969b). Effect of precooking of Baltic herring on lipid hydrolysis during subsequent cold storage. Lebensmittel Wissenschaft und Technologie 2: 59-61.

Bosund I. and Ganrot B. (1970). Effect of precooking on lipid oxidation and storage life of frozen fish. Lebensmittel Wissenschaft und Technologie 3: 71-73.

Boyd L., Green D., Giesbrecht F. and King M. (1993). Inhibition of oxidative rancidity in frozen cooked fish flakes by tert-butylhydroquinone and Rosemary extract. Journal of the Science of Food and Agriculture 61: 87-93.

Bykowski P., Zalewski J. and Gora A. (1990). Shelf life of frozen squid (Illex patagonicus). In Chilling and Freezing of New Fish Products. Meeting of Commission C2, Aberdeen (UK). Paris: International Institute of Refrigeration, pp. 203-208

Callegarin F., Quezada J., Debeaufort F. and Voilley A. (1997). Lipids and biopackaging. Journal of the American Oil Chemists' Society 74: 1183-1192.

Careche M. and Tejada M. (1994). Hake natural actomyosin interaction with free fatty acids during frozen storage. Journal of the Science of Food and Agriculture 64: 501-507.

Castrillón A., Alvarez-Pontes E. and García-Arias M. (1996). Influence of frozen storage and defrosting on the chemical and nutritional quality of sardine (Clupea pilchardus). Journal of the Science of Food and Agriculture 70: 29-34.

Castrillón A., Navarro, P. and García-Arias, M. (1996). Tuna protein nutritional quality changes after canning. Journal of Food Science 61: 1250-1253.

Cheftel J. and Cheftel H. (1976). Introducción a la Bioquímica 
y Tecnología de Alimentos. Vol. 1. Zaragoza, Spain: Acribia. pp. 65-97.

Cheftel J., Cheftel H. and Besançon P. (1976). Introducción a la Bioquímica y Tecnología de Alimentos. Vol. 2. Zaragoza, Spain: Acribia. pp. 236-276.

Chow C., Ochiai Y., Watabe S. and Hashimoto K. (1987). Autoxidation of bluefin tuna myoglobin associated with freezing and thawing. Journal of Food Science 52: 589-591, 625.

Damoglou A. (1980). A comparison of different methods of freshness assessment of herring. In: Connell, J. (ed.), Advances in Fish Science and Technology. Farnham, Surrey (UK): Fishing News Books Ltd. pp. 394-399.

Davies A. (1997). Modified-atmosphere packaging of fish and fish products. In: Hall G. (ed.), Fish Processing Technology. London: Blackie Academic and Professional. pp. 200-223.

Decker E. (1998). Strategies for manipulating the prooxidative/antioxidative balance of foods to maximize oxidative stability. Trends in Food Science and Technology 9: 241-248.

EC (1989). Baremo de clasificación de frescura. Diario Oficial de las Comunidades Europeas No. L 5/21, pp. 5-6.

El Marrakchi A., Bennour M., Bouchriti N., Hamama A., and Tagafait H. (1990). Sensory, chemical and microbiological assessments of Maroccan sardines (Sardina pilchardus) stored on ice. Journal of Food Protection 53: 600-605.

Erickson M. (1997a). Lipid oxidation: Flavor and nutritional quality deterioration in frozen foods. In: Erickson M. and Hung Y.-C. (eds), Quality in Frozen Food. New York: Chapman and Hall. pp. 141-173.

Erickson M. (1997b). Antioxidants and their application to frozen foods. In: Erickson M. and Hung Y.-C. (eds), Quality in Frozen Foods. New York: Chapman and Hall. pp. 233-263.

Erikson U., Beyer A. and Sigholt T. (1997). Muscle highenergy phosphates and stress affect $K$-values during ice storage of Atlantic salmon (Salmo salar). Journal of Food Science 62: 43-47.

FAO (2000). Fishery Statistics, Yearbook 1998. Rome: FAO.

Fernández-Salguero J. and Mackie, I. (1987). Comparative rates of spoilage of fillets and whole fish during storage of haddock (Melanogrammus aeglefinus) and herring (Clupea harengus) as determined by the formation of non-volatile and volatile amines. International Journal of Food Science and Technology 22: 385-390.

Frankel E. (1995). Natural and biological antioxidants in foods and biological systems. Their mechanism of action, applications and implications. Lipid Technology July: 77-80.

Gall K., Otwell W., Korurger J. and Appledorf H. (1983). Effects of four cooking methods on the proximate, mineral and fatty acid composition of fish fillets. Journal of Food Science 48: 1068-1074.

Gallardo J., Aubourg S. and Pérez-Martín R. (1989). Lipid classes and their fatty acids at different loci of albacore (Thunnus alalunga): Effects of precooking. Journal of Agricultural and Food Chemistry 37: 1060-1064.

Gallardo J., Pérez-Martín R., Franco J., Aubourg S. and Sotelo
C. (1990). Changes in volatile bases and trimethylamine oxide during the canning of albacore (Thunnus alalunga). International Journal of Food Science and Technology 25: 78-81.

Gallardo J., Sotelo C. and Pérez-Martín R (1997). Determination of histamine by capillary zone electrophoresis using a low-pH phosphate buffer: Application in the analysis of fish and marine products. Zeitschrift für LebensmittelUntersuchung und Forschung 204: 336-340.

García-Arias T., Sánchez-Muniz J., Castrillón A. and Navarro P. (1994). White tuna canning, total fat, and fatty acid changes during processing and storage. Journal of Food Composition and Analysis 7: 119-130.

Geiger E. and Borgstrom G. (1962). Fish protein-nutritive aspects. In: Borgstrom G. (ed.), Fish as Food. Vol. 2. New York: Academic Press. pp. 29-114.

Giddings G. and Hill L. (1975). Processing effects on the lipid fractions and principal fatty acids of blue crab (Callinectes sapidus) muscle. Journal of Food Science 40: 1127-1129.

Gill T., Thompson J., Gould S. and Sherwood D. (1987). Characterization of quality deterioration in yellowfin tuna. Journal of Food Science 52: 580-583.

Haard N. (1992). Biochemical reactions in fish muscle during frozen storage. In: Bligh E. (ed.), Seafood Science and Technology. Oxford, UK: Fishing News Books.

Hale M. and Brown T. (1983). Fatty acids and lipid classes of three underutilized species and changes due to canning. $M a-$ rine Fisheries Review 45: 4-6.

Han T-J. and Liston J. (1987). Lipid peroxidation and phospholipids hydrolysis in fish muscle microsomes and frozen fish. Journal of Food Science 52: 294-299.

Harris P. and Tall J. (1994). Rancidity in fish. In: Allen, J.C. and Hamilton, R.J. (eds), Rancidity in Foods. London: Chapman and Hall. pp. 256-272.

Hearn T., Sgoutas S., Sgoutas D. and Hearn, J. (1987). Polyunsaturated fatty acids and fat in fish flesh for selecting species for health benefits. Journal of Food Science 52: 1209-1211.

Horner W. (1997). Canning fish and fish products. In: Hall G. (ed.), Fish Processing Technology. 2nd edn. London: Blackie Academic and Professional, Chapman and Hall. pp. 119-159.

Hsieh R. and Kinsella J. (1989). Oxidation of polyunsaturated fatty acids: mechanisms, products, and inhibition with emphasis on fish. Advances in Food Research and Nutritional Research 33: 233-341.

Hurrell R. and Carpenter K. (1977). Maillard reactions in foods. In: Høyem T. and Kvale O. (eds.), Physical, Chemical and Biological Changes in Food Caused by Thermal Processing. London: Applied Science Publishers. pp. 168-184.

Hwang K. and Regenstein J. (1993). Characteristics of mackerel mince lipid hydrolysis. Journal of Food Science 58: 79-83.

Illingworth D. and Ullmann D. (1990). Effects of omega-3 fatty acids on risk factors for cardiovascular disease. In: Lees R. and Karel M. (eds.), Omega-3 Fatty Acids in Health and Disease. New York and Basel: Marcel Dekker, Inc., pp. 39-69. 
Jian S., Tsao C. and Lee T. (1987). Effect of free amino acids on the denaturation of mackerel myofibrillar proteins in vitro during frozen storage at $-20^{\circ} \mathrm{C}$. Journal of Agricultural and Food Chemistry 35: 28-33.

Joshi V. and Saralaya K. (1982). Studies on the effect of precooking in sardine canning: V. Factors influencing the precooking effect. Mysore Journal of Agricultural Science 16: 338-345.

Karaçam H. and Boran M. (1996). Quality changes in frozen whole and gutted anchovies during storage at $-18{ }^{\circ} \mathrm{C}$. International Journal of Food Science and Technology 31: 527-531.

Ke P., Ackman R., Linke B. and Nash D. (1977). Differential lipid oxidation in various parts of frozen mackerel. Journal of Food Technology 12: 37-47.

Kelleher S., Silva L., Hultin H. and Wilhelm K. (1992). Inhibition of lipid oxidation during processing of washed, minced Atlantic mackerel. Journal of Food Science 57: 1103-1108, 1119.

Khalil A. and Mansour E. (1998). Control of lipid oxidation in cooked and uncooked refrigerated carp fillets by antioxidant and packaging combinations. Journal of Agricultural and Food Chemistry 46: 1158-1162.

Kramer A. (1982). Effect of storage on nutritive value of food. In: Rechcilg M. (ed.), Handbook of Nutritive Value of Processed Food. Vol. 1. Boca Raton, FL: CRC Press. pp. 275-299.

Kurade S. and Baranowski J. (1987). Prediction of shelf-life of frozen minced fish in terms of oxidative rancidity as measured by TBARS number. Journal of Food Science 52: 300-302, 311

Loaharanu P. (1995). Food irradiation: current status and future prospects. In: Gould G. (ed.) New Methods of Food Preservation. London: Blackie Academic and Professional. pp. 90-111.

López A. (1987). A Complete Course in Canning and Related Processes. Vol. II. Baltimore, US: The Canning Trade, Inc. pp. 68-87.

López-Sabater E., Rodríguez-Jerez J., Roig-Sagués A. and Mora-Ventura M. (1994). Bacteriological quality of tuna fish (Thunnus thynnus) destined for canning: Effect of tuna handling on presence of histidine decarboxylase bacteria and histamine level. Journal of Food Protection 57: 318-323.

Lund D. (1975). Heat processing. In: Karel M., Fennema O., and Lund D. (eds), Principles of Food Science, Part II. Physical Principles of Food Preservation. New York and Basel: Marcel Dekker, Inc. pp. 31-92.

MacDonald G. and Lanier T. (1997). Cryoprotectants for improving frozen-food quality. In: Erickson M. and Hung Y.-C. (eds), Quality in Frozen Food. New York: Chapman and Hall, International Thompson Publishing. pp. 197-232.

Mackie I. (1993). The effects of freezing on flesh proteins. Food Reviews International 9: 575-610.

Madrid A., Madrid J. and Madrid R. (1994). Tecnología del Pescado y Productos Derivados. Madrid: A. Madrid Vicente, Ediciones y Mundi-Prensa Libros, S.A. pp. 45-56.

Maeda Y., Ishikawa M., Yamamoto M., Terada S., Masui T. and Watanabe Y. (1985). Effect of cooking on contents of fatty acids, especially eicosapentaenoic acid and docosahexaenoic acid in sardine. Journal of the Japan Society of Nutrition and Food Science 38: 447-450.

Mallikarjunan P. and Hung Y.-C. (1997). Physical and ultrastructural measurements. In: Erickson M. and Hung Y.-C. (eds.), Quality in Frozen Food. New York: Chapman and Hall. pp. 313-339.

March B. (1982). Effect of processing on nutritive value of food: Fish. In: Rechcigl Jr. M. (ed.), Handbook of Nutritive Value of Processed Food. Boca Raton, FL: CRC Press. pp. 363-381.

Medina I., Aubourg S. and Pérez-Martín R. (1993). Analysis of 1-O-alk-1-enylglycerophospholipids of albacore tuna (Thunnus alalunga) and their alterations during thermal processing. Journal of Agricultural and Food Chemistry 41: 2395-2399.

Medina I., Sacchi R. and Aubourg S. (1994). ${ }^{13}$ C-NMR monitoring of FFA release after fish thermal processing. Journal of the American Oil Chemists' Society 71: 479-482.

Medina I., Sacchi R. and Aubourg S. (1995). A ${ }^{13}$ C-NMR study of lipid alterations during fish canning: Effect of filling medium. Journal of the Science of Food and Agriculture 69: $445-450$.

Medina I., Sacchi R., Biondi L., Aubourg S. and Paolillo L. (1998). Effect of packing media on the oxidation of canned tuna lipids. Antioxidant effectiveness of extra virgin olive oil. Journal of Agricultural and Food Chemistry 46: 1150-1157.

Nair P., George C., Thampuran N., Perigreen P. and Gopakumar K. (1987). Studies on frozen storage characteristics of individually quick frozen and block frozen mackerel. Fishery Technology 24: 103-108.

Nishimoto J. and Koreeda N. (1979). Protein denaturation and the change of gel-forming capacity in the rinsed fish muscle during frozen storage. Bulletin of the Japan Society of Scientific Fisheries 45: 989-993.

Nunes M., Batista I. and Morao de Campos R. (1992). Physical, chemical and sensory analysis of sardine (Sardina pilchardus) stored in ice. Journal of the Science of Food and Agriculture 59: 37-43.

Ólafsdóttir G., Martinsdóttir E., Oehlenschläger J., Dalgaard P., Jensen B., Undeland I., Mackie I., Henehan G., Nielsen J. and Nilsen H. (1997). Methods to evaluate fish freshness in research and industry. Trends in Food Science and Technology 8: $258-265$.

Oliveira L., Mali L., Sarantopoulos C., Mori E. and Shirose I. (1986). Processed tuna fish: Potential for an alternative package. Boletim do Instituto Tecnologico dos Alimentos (Campinas, Brazil) 23: 117-125.

Pérez-Martín R., Banga J., Sotelo C., Aubourg S. and Gallardo J. (1989). Prediction of precooking times for albacore (Thunnus alalunga) by computer simulation. Journal of Food Engineering 10: 83-95.

Pérez-Martín R., Franco J., Aubourg S. and Gallardo J. (1988). Changes in free amino acids content in albacore (Thunnus alalunga) muscle during thermal processing. Zeitschrift für Lebensmittel-Untersuchung und Forschung 187: 432-435.

Pérez-Villarreal B. and Pozo R. (1990). Chemical composition 
and ice spoilage of albacore (Thunnus alalunga). Journal of Food Science 55: 678-682.

Piclet G. (1987). Le poisson aliment: Composition, intérêt nutritionnel. Cahiers de Nutrition et Diététique 22: 317-335.

Pigott G. and Tucker B. (1987). Science opens new horizons for marine lipids in human nutrition. Food Reviews International 3: 105-138.

Pigott G. and Tucker B. (1990). Seafood. Effects of Technology on Nutrition. New York and Basel: Marcel Dekker, Inc. pp. 104-135.

Refsgaard H., Brockhoff P. and Jensen B. (1998). Sensory and chemical changes in farmed Atlantic salmon (Salmo salar) during frozen storage. Journal of Agricultural and Food Chemistry 46: 3473-3479.

Rodríguez C., Fernández J. and Pascual C. (1996). Evolución de los productos de degradación del ATP durante el proceso de elaboración de conservas de sardina. Alimentaria Julio/Agosto: 81-85.

Ruiz-Roso B., Cuesta I., Pérez M., Borrego E., Pérez-Olleros L. and Vare G. (1998). Lipid composition and palatability of canned sardines. Influence of the canning process and storage in olive oil for five years. Journal of the Science of Food and Agriculture 77: 244-250.

Schellekens M. (1996). New research issues in sous-vide cooking. Trends in Food Science and Technology 7: 256-262.

Seet S. and Brown D. (1983). Nutritional quality of raw, precooked and canned albacore tuna (Thunnus alalunga). Journal of Food Science 48: 288-289.

Seidler T. and Bronowski M. (1987). Effects of storage time and thermal treatment on the nutritive value of squid (Illex argentinus). Nahrung 31: 949-957.

Shenouda S. (1980). Theories of protein denaturation during frozen storage of fish flesh. Advances in Food Research 26: $275-311$.

Simeonidou S., Govaris A. and Vareltzis K. (1997). Effect of frozen storage on the quality of whole fish and fillets of horse mackerel (Trachurus trachurus) and Mediterranean hake (Merluccius mediterranean). Zeitschrift für LebensmittelUntersuchung und Forschung 204: 405-410.

Simopoulos A. (1997). Nutritional aspects of fish. In: Luten J., Børresen T. and Oehlenschläger J. (eds.), Seafood from Producer to Consumer, Integrated Approach to Quality. Amsterdam: Elsevier. pp. 589-607.

Sims G., Farn G. and York R. (1992). Quality indices for canned skipjack tuna: Correlation of sensory attributes with chemical indices. Journal of Food Science 57: 1112-1115.

Slabyj B. and True R. (1978). Effect of preprocess holding on the quality of canned Maine sardines. Journal of Food Science 43: 1172-1176.

Smith J., Hardy R., MacDonald I. and Templeton J. (1980). The storage of herring (Clupea harengus) in ice, refrigerated sea water and at ambient temperature. Chemical and sensory assessment. Journal of the Science of Food and Agriculture 31: 375-385.

Stansby E. (1979). Canning of marine products. In: Jackson J. and Shinn B. (eds), Fundamentals of Food Canning Tech- nology. Westport, Connecticut (USA): AVI Publishing Company, Inc. pp. 253-273.

Suzuki H., Chung S., Isobe S., Hayakawa S. and Wada S. (1988). Changes in $\omega-3$ polyunsaturated fatty acids in the chum salmon muscle during spawning migration and extrusion cooking. Journal of Food Science 53: 1659-1661.

Tanaka M. and Kimura S. (1988). Effect of heating conditions on protein quality of retort pouched fish meat. Nippon Suisan Gakkaishi 54: 265-270.

Tichivangana J. and Morrisey P. (1982). Lipid oxidation in cooked fish muscle. Irish Journal of Food Science and Technology 6: 157-163.

Tokunaga T. (1975). Studies on the quality evaluation of canned marine products. I. Determination of the ratio of dimethylamine to trimethylamine in canned albacore. Bulletin of the Japanese Society of Scientific Fisheries 41: 547-553.

Undeland I. and Lingnert H. (1999). Lipid oxidation in fillets of herring (Clupea harengus) during frozen storage. Influence of prefreezing storage. Journal of the Agricultural and Food Chemistry 47: 2075-2081.

Undeland I., Ekstrand B. and Lingnert H. (1998). Lipid oxidation in minced herring (Clupea harengus) during frozen storage. Effect of washing and precooking. Journal of the Agricultural and Food Chemistry 46: 2319-2328.

Undeland I., Hall G. and Lingnert H. (1999). Lipid oxidation in fillets of herring (Clupea harengus) during ice storage. Journal of the Agricultural and Food Chemistry 47: 524-532.

Undeland I., Stading M. and Lingnert H. (1998). Influence of skinning on lipid oxidation in different horizontal layers of herring (Clupea harengus) during frozen storage. Journal of the Science of Food and Agriculture 78: 441-450.

Vareltzis K., Koufidis D., Graviilidou E., Papavergou E. and Vasiliadou S. (1997). Effectiveness of a natural Rosemary (Rosmarinus officinalis) extract on the stability of filleted and minced fish during frozen storage. Zeitschrift für Lebensmittel-Untersuchung und Forschung 205: 93-96.

Veciana-Nogués M., Mariné-Font A. and Vidal-Carou M. (1997). Biogenic amines in fresh and canned tuna. Effects of canning on biogenic amine contents. Journal of Agricultural and Food Chemistry 45: 4324-4328.

Verma J., Srikar L., Sudhakara N. and Sarma J. (1995). Effects of frozen storage on lipid freshness parameters and some functional properties of oil sardine (Sardinella longiceps) mince. Food Research International 28: 87-90.

Vieites J., Ruiz C. and García M. (1997). Influencia de la relación tiempo-temperatura en la calidad de la conserva de atún en aceite: Aspectos tecnológicos. Alimentaria Diciembre: $103-112$.

Wang Y.-J., Miller L. and Addis P. (1991). Effect of heat inactivation of lipoxygenase on lipid oxidation in lake herring (Coregonus artedii). Journal of the American Oil Chemists' Society 68: 752-757.

Whittle K., Hardy R. and Hobbs G. (1990). Chilled fish and fishery products. In: Gormley T. (ed.), Chilled Foods. The State of the Art. London and New York: Elsevier Applied Science. pp. 87-116. 
Xiong Y. (1997). Protein denaturation and functionality losses. In: Erickson M. and Hung Y.-C. (eds), Quality in Frozen Food. New York: Chapman and Hall. pp. 111-140.

Yamamoto Y. and Imose K. (1989). Changes in fatty acid composition in sardines (Sardinops melanosticta) with cooking and refrigerated storage. Journal of Nutritional Science and Vitaminology 35: 39-47.
Yeannes M., del Valle C. and Lupin H. (1983). Generación de bases nitrogenadas volátiles durante el proceso de elaboración de conservas de pescado. Revista de Agroquímica y Tecnología de Alimentos 23: 585-590.

Zotos A., Hole M. and Smith G. (1995). The effect of frozen storage of mackerel (Scomber scombrus) on its quality when hot-smoked. Journal of the Science of Food and Agriculture 67: $43-48$ 